\title{
Model of Above-ground Biomass Distribution of Norway Spruce (Picea abies L. (Karst.))
}

\author{
Oskars Krišāns, Valters Samariks, Roberts Matisons, and Āris Jansons * \\ Climate change with more frequent extreme weather events and \\ prolonged winter periods with un-frozen, wet soil is causing frequent wind \\ damage events in forests. Trees with higher mass point and heavier \\ weight are more prone to wind damage; however, limited information \\ exists on distribution of biomass under naturally moist conditions. Such \\ information is essential to improve models of wind damage prediction. \\ Therefore, the aim of the present study was to assess the biomass \\ distribution and the parameters important for wind-load of Norway spruce \\ (Picea abies (L.) Karst.). Samples were collected in the year 2019 from 87 \\ trees growing on two different sites, corresponding to freely drained \\ mineral and peaty mineral soils at the age of 55 and 88 years, respectively. \\ Tree diameters at breast height, height, and height of first living branch \\ were measured. Tree stems were pruned and cut into 2-m-long fragments \\ and weighed (fresh weight) afterwards. A biomass distribution model was \\ developed to estimate fresh weight of the stem of Norway spruce using \\ easy measurable tree variables. Relative height of the mass point and \\ height of living branches were higher in peaty mineral soil than on freely \\ drained mineral soil, which was an indicator for higher windthrow risks.
}

Keywords: Fresh weight; Gales; Mass point height; Storm; Wind load; Windthrow

Contact information: Latvia State Forest Research Institute "Silava", Rìgas St. 111. Salaspils, LV-2169, Latvia; *Corresponding author: aris.jansons@ silava.lv

\section{INTRODUCTION}

Future climate change scenarios predict an increase in mean air temperature and extreme weather events (wind (storm) intensity and frequency) (IPCC 2019). Yet another effect of climate change is winter with long periods of un-frozen, wet soil, and thus difficult logging conditions (Peltola et al. 2010). Therefore, wind damage to trees is considered to be a major problem in the future, with the potential to result in notable economic losses (Von Gadow and Hui 2001). This is a concern especially for Norway spruce (Picea abies (L.) Karst.) because of the shallow root system and increased susceptibility to various hazards such as storms, droughts, insects, or diseases (Greiss et al. 2012; Caudullo et al. 2016).

Diverse biomass estimation models have been developed (Classon et al. 2001; Lehtonen et al. 2004; Wirth et al. 2004; Zianis et al. 2005; Mikšys et al. 2007; Pajtik et al. 2008; Repola 2009; Socha 2012) based on easily measurable tree variables. Most of the developed tree biomass models were expressed as dry weight for prediction of outcome of sawn good, calorific value of energy wood, although the models of biomass for possible wind damage should be expressed as fresh weight. Therefore, complex dynamic wind-load prediction models (Moore and Maguire 2007; Sellier et al. 2008; Pivato et al. 2014), and several static wind damage prediction models (HWIND, GALES, and FOREOLE) have been developed (Peltola et al. 1999; Gardiner et al. 2000; Ancelin et al. 2004). Only the

Krišāns et al. (2020). "Spruce above-ground biomass," BioResources 15(2), 4314-4322. 4314 
FOREOLE model used the approach that trees were divided into successive ( 1 to $2 \mathrm{~m}$ long) fragments for assessment of biomass distribution (Ancelin et al. 2004). Accuracy of all the models can be improved by adding empirical data where their availability is limited. The tree wind resistance depends on its root system, mechanical strength of the stem, and biomass (amount and distribution) (Peltola et al. 1999; Cucchi et al. 2005; Scott and Mitchell 2005). Therefore, the tree height of the mass point (centre of mass) may be used as proxy to estimate the risks of windthrow (Cucchi et al. 2005; Nicoll et al. 2006).

The aim of present study was to assess the biomass distribution and parameters important for wind-load of Norway spruce (Picea abies (L.) Karst.).

\section{EXPERIMENTAL}

\section{Materials}

The study was conducted in trial sites located in Kalsnava, in the eastern part of Latvia $\left(56^{\circ} 41 \mathrm{~N}, 25^{\circ} 50 \mathrm{E}\right.$ and $\left.56^{\circ} 41 \mathrm{~N}, 25^{\circ} 52 \mathrm{E}\right)$. The sites were situated on a flat relief, where the elevation was approximately 100 to 120 m.a.s.l (Spalvins et al. 2012). Materials were collected in Norway spruce stands growing on different soil types, corresponding to Myrtillosa melior forest type with freely drained mineral soil (A1) and typically with shallow root system, and Myrtillosa turf melior type with peaty mineral soil (C1), and root depth < 40 cm (Bušs 1976; Pyatt 1982, 2001; Kennedy 2002).

In total, 87 first layer trees were randomly selected: 47 trees from the diameter at breast height $(\mathrm{DBH})$ that ranged from 25.8 to $40.6 \mathrm{~cm}$ from $\mathrm{A} 1$ at the age of 55 years old, and 40 trees (DBH ranged from 23.8 to $44.3 \mathrm{~cm}$ ) from $\mathrm{C} 1$, that were 88 years old, were sampled in winter 2019. Tree height ranged from 23 to $28.9 \mathrm{~m}$ in A1 and 24.2 to $31.1 \mathrm{~m}$ in $\mathrm{C} 1$. Cutting was done as close as possible to the root collar. The DBH, tree height $(\mathrm{H})$, and height of the lowest living branch $\left(\mathrm{H}_{\mathrm{lb}}\right)$ were measured for each tree. Tree stems were pruned, cut into 2-m-long fragments, weighed (fresh weight), and diameter measured in the middle point of each fragment. Total branch weight of a tree was measured after all the small branches from the stem were removed, however, only living branches were weighed excluding dead and dry branches.

\section{Methods}

\section{Data analysis}

All biomass prediction variables corresponded to normal distribution. A linear mix effects model was used to apply the model for Norway spruce biomass prediction based on the $\mathrm{DBH}, \mathrm{H}$, height of the fragments middle point, or the combination of these parameters. Pearson's correlation analysis was introduced to assess the relationship between tree biomass and model prognosis, and relationships between measured variables. Principle component analysis was employed to examine the effect of soil type on tree variables and to discover the relationship between the studied samples.

Each tree's height of mass point $\left(H_{\mathrm{mp}}\right)$ was calculated with the average weighed value of height of the middle point and the mass of each part of the tree (tree fragments) as,

$$
H_{\mathrm{mp}}=\frac{\sum m \times h}{\sum h}
$$


where $m$ is the mass of part of the tree $(\mathrm{kg})$ and $h$ is the height of middle point of part of the tree $(\mathrm{m})$.

The relative height of mass point $\left(\right.$ rel. $\mathrm{H}_{\mathrm{mp}}$ ) is a proportion of the total tree height. All steps of the data analysis were completed using the statistical software R 3.6.1. (R Core Team 2019, Vienna, Austria).

\section{RESULTS AND DISCUSSIONS}

\section{Biomass Distribution Model}

The model was based on DBH and $\mathrm{H}$, which are commonly used as independent variables in biomass models of Marklund (1988) and Repola (2009). The mean total aboveground biomass $(95 \%$ confidence interval, CI) of Norway spruce was $66.36 \pm 2.97 \mathrm{~kg}$. All analysed variables were statistically significant $(\mathrm{p}<0.001)$; however the strength of the correlations differed (Table 1). A high correlation between the stem fresh weight (stem weight with water and bark, but without needles and branches) and modelled weight prognosis (estimated fresh weight with water and bark, but without branches) $(r=0.98)$ indicated nearly the same variation and high model accuracy. Moreover, high correlation $(\mathrm{r}=0.79)$ between the tree dimensions (DBH and $\mathrm{H})$ exhibited similar variation pattern; therefore, the use of these variables can provide an estimation of tree above-ground biomass.

Table 1. Pairwise Pearson's Correlation Coefficients (Below Diagonal) and Significance ( $p$-values - Above Diagonal) Among Variables of Norway Spruce

\begin{tabular}{|c|c|c|c|c|}
\hline Variable & DBH & H & $\begin{array}{c}\text { Stem Fresh } \\
\text { Weight (kg) }\end{array}$ & $\begin{array}{c}\text { Estimated } \\
\text { Biomass (kg) }\end{array}$ \\
\hline DBH & 1 & $<0.001$ & $<0.001$ & $<0.001$ \\
\hline H & 0.79 & 1 & $<0.001$ & $<0.001$ \\
\hline Stem Fresh Weight $\mathbf{( k g )}$ & 0.36 & 0.29 & 1 & $<0.001$ \\
\hline Estimated Biomass $\mathbf{( k g )}$ & 0.39 & 0.32 & 0.98 & 1 \\
\hline
\end{tabular}

Models of biomass distribution predicted stem fragment fresh weight and compared the predictions with an actual stem fragment weight (Fig. 1). In general, the developed model showed a good fit to the stem weight data, as shown by the coefficient of determination $\left(\mathrm{R}^{2}=0.95\right)$.

Most of the models predicted dry wood biomass (Marklund 1988; Repola 2009), but the authors' model was a prediction of fresh stem wood biomass, as it was necessary for the assessment of the wind load effect. Model prognosis varied most with a prediction of first stem fragment weight (Fig. 1), which can be explained that the lower and thicker parts of the stem (which was primarily the first fragment) were the heaviest and their weight varied the most. A majority of the biomass models underestimate the actual tree biomass, and their predictions are lower than the real weight (Libiete et al. 2017; Kenina et al. 2018). However, the authors' model overestimated the prognosis, as indicated by mean estimated biomass $(84.66 \pm 4.03 \mathrm{~kg}, 95 \%$ confidence interval). Results differ because most dry wood biomass models (belowground or aboveground) predict stem weight when trees have dried and lost a majority of stored stem water (Marklund 1988; Repola 2009; Lỉbiete et al. 2017; Kenina et al. 2018), while prediction of stem fresh weight biomass includes additional weight of water in the stem (amount of water varies noticeably).

Krišāns et al. (2020). "Spruce above-ground biomass," BioResources 15(2), 4314-4322. 4316 


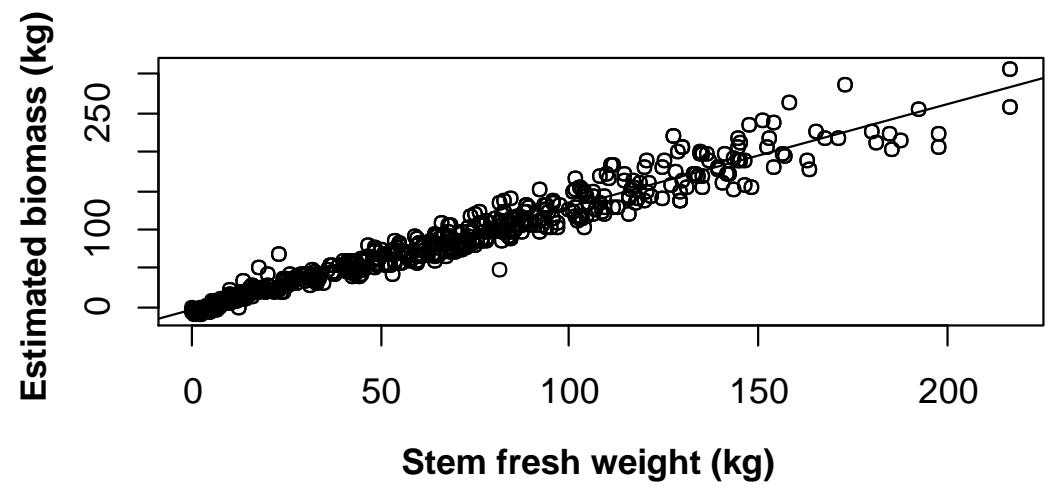

Fig. 1. Biomass distribution prognosis $(\mathrm{kg})$ of Norway spruce against stem fresh weight $(\mathrm{kg})$

\section{Component comparison}

Principle component analysis (PCA) determined that approximately $83 \%$ of explainable variances were located in the first and second components (Fig. 2A), with proportions of $53.2 \%$ and $30.4 \%$, respectively.
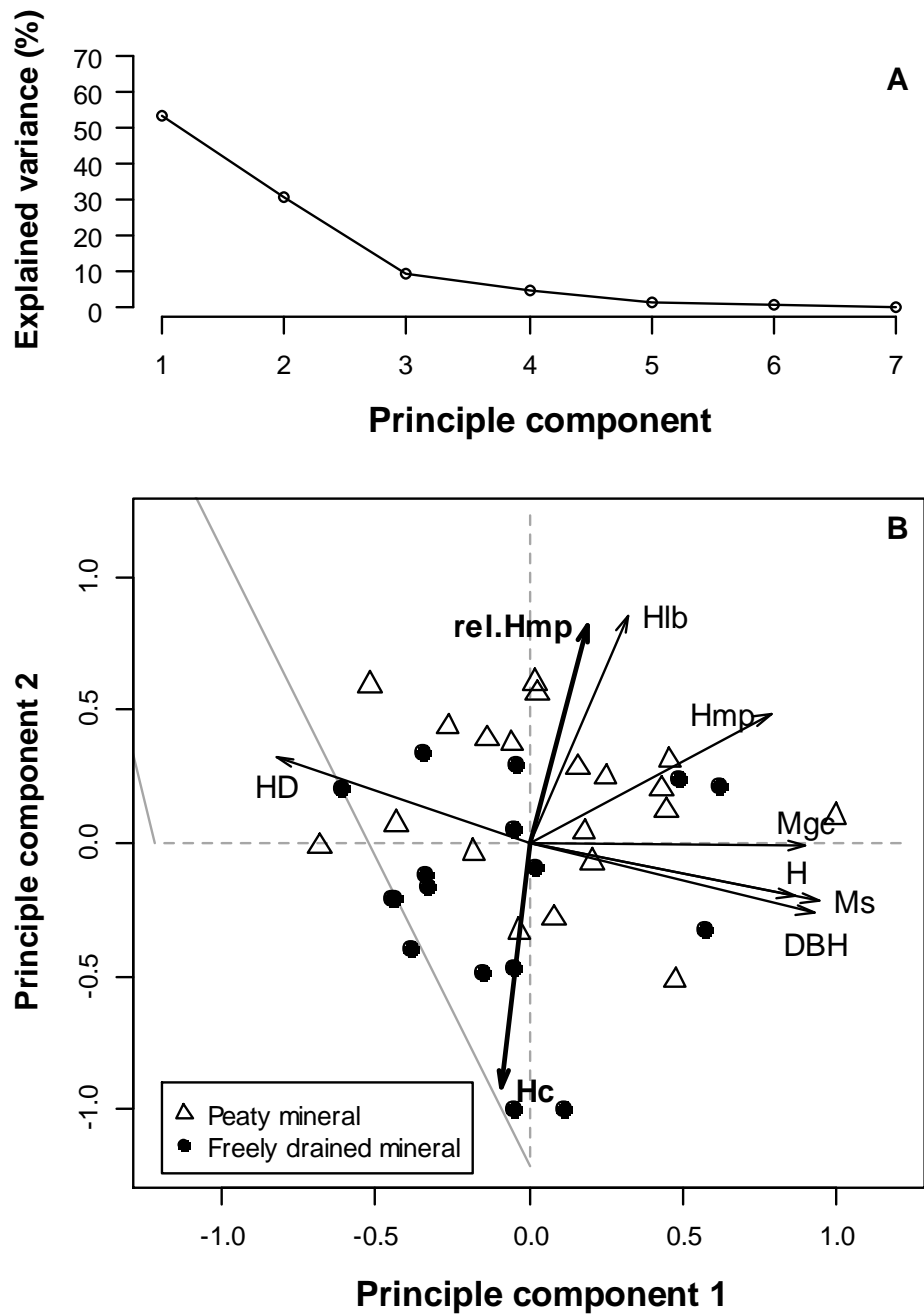

Fig. 2. Explained variance (\%) of principle component (A); distribution and correlation between the studied trees in the vector space (B), where DBH: diameter at breast height; $M_{s}$ : mass of stem, $\mathrm{M}_{\mathrm{gc}}$ : mass of green crown; $\mathrm{H}$ : height, $\mathrm{H}_{\mathrm{lb}}$ : height of the lowest living branch; $\mathrm{H}_{\mathrm{mp}}$ : mass point height; rel. $\mathrm{H}_{\mathrm{mp}}$ : relative mass point height; $\mathrm{HD}$ : slenderness ratio; $\mathrm{H}_{\mathrm{c}}$ : relative canopy height 
The PCA between the first two components was used to explain the effect of soil type on Norway spruce variables. The first component was associated with tree variables: $H$, DBH, mass of stem fresh weight $\left(M_{\mathrm{s}}\right)$, mass of green canopy $\left(M_{\mathrm{gc}}\right), H_{\mathrm{mp}}$, and slenderness ratio (HD). The second component was related to canopy parameters: rel. $H_{\mathrm{mp}}, H_{\mathrm{lb}}$, and relative height of crown $\left(H_{\mathrm{c}}\right)$ (Fig. 2B). Moreover, the second component had a statistically significant relationship with soil type.

More than $53.2 \%$ of explainable variations of first component were not affected by soil type; however, there was a strong correlation with $H, \mathrm{DBH}, M_{\mathrm{s}}$, and $M_{\mathrm{gc}}$ (Fig. 2B). Stem mass was tightly correlated with DBH $(\mathrm{r}=0.95), H(\mathrm{r}=0.85)$, and $M_{\mathrm{lb}}(\mathrm{r}=0.83)$, which indicated a significance of effects of DBH $(\mathrm{p}<0.01)$ and $H(\mathrm{p}<0.01)$ on stem biomass variation, where the increase in these variables directly increased stem weight. Further, stem mass was used to assess tree's height of the mass point, and this parameter is dependent on various tree variables, such as height, $\mathrm{DBH}$, and tree weight, of which $H_{\mathrm{mp}}$ was generally determined. Therefore, if tree height and diameter increases, then the height of a mass point also increases in most cases, and the correlation $(r=0.64)$ between these variables indicated that $H_{\mathrm{mp}}$ and height of tree had similar pattern of variation. Height of mass point was significantly and tightly correlated $(\mathrm{r}=0.77)$ with the $M_{\mathrm{gc}}$, and it had a moderate correlation with most of the analysed variables, such as $M_{\mathrm{s}}(\mathrm{r}=0.61)$, DBH $(\mathrm{r}=$ $0.55), H(\mathrm{r}=0.64)$, and $H_{\mathrm{lb}}(\mathrm{r}=0.57)$. In the analysis, $H_{\mathrm{mp}}$ was used to describe tree resistance to wind-load.

If the mass point height was located lower, then the resistance was greater and vice versa (Cucchi et al. 2005; Nicoll et al. 2006). Correlation between $\mathrm{H}_{\mathrm{mp}}$ with all the abovementioned variables indicated that properties of stem and crown might influence the potential susceptibility to wind damage, as it directly affects height of the mass point. However, biomass distribution might differ between trees because of the stem and crown architecture (Jansons et al. 2014). Slenderness ratio had a tight inverse correlation with $\mathrm{DBH}(\mathrm{r}=-0.91)$, which indicates that with an increase in stem diameter tree HD ratio decreases, resulting in possibly higher resistance for wind load on a tree level (Mickovski et al. 2005). Taller and narrower trees with HD value over 1 are more susceptible to windthrow (Rudnicki et al. 2004) and have higher probability of being uprooted or snapped.

Another $30.4 \%$ of explainable variances of the second component were affected by soil type ( $\mathrm{p}<0.008)$, and they were positively correlated with rel. $H_{\mathrm{mp}}, H_{\mathrm{lb}}$, and negatively with $H_{\mathrm{c}}$ (Fig. 2B). Relative height of the mass point is from $34 \%$ to $44 \%$ of the whole tree height. For spruce with a relatively smaller canopy size, the whole tree mass point height was located higher $(\mathrm{p}<0.001)$, resulting in unevenly balanced weight.

The tree's canopy serves as a 'sail' to catch larger wind loads and with a taller tree stem (the lever arm), the probability of wind damages increases (Gardiner et al. 2008; Schindler et al. 2012). Therefore, they were less resistant to wind-load damages (resulting in either stem breakage or windthrow) as less wind force is needed because of the vertical force applied due to gravity, including the crown and stem weight (Peltola et al. 1999). Results indicated that tree canopy on peaty mineral soils might be smaller in comparison to those growing on freely drained mineral soils. Additionally, trees growing on peaty mineral soils had poorer anchorage than on any other soil, similar results have been reported by Nicoll (2006). Thus, spruce growing on peaty soil need lower critical wind speed at which the damages occur.

Krišāns et al. (2020). "Spruce above-ground biomass," BioResources 15(2), 4314-4322. 4318 


\section{CONCLUSIONS}

1. A biomass distribution model was successfully applied using easy measurable variables for prediction of stem fresh weight. Biomass model was a useful tool for the aboveground biomass estimation for Norway spruce.

2. Principle component analysis revealed $83.7 \%$ of explainable variances in the first two components of which $53.2 \%$ of explainable variances were affected by height, diameter at breast height, stem and canopy weight, and height of the mass point. Trees with relatively higher stem mass and mass point height located lower will have a higher chance to survive extreme wind loads (storms).

3. Other $30.4 \%$ of variance were affected by soil type, indicating that spruce on peaty mineral soil had relatively smaller canopy; thus rel. $H_{\mathrm{mp}}$ was located higher, which resulted in less resistant to wind load. Accordingly, the relative height of the mass point was a significant variable for determination of wind damage risks. Trees growing on peaty soil had a higher wind damage risk than tree growing on fresh mineral soil.

\section{ACKNOWLEDGMENTS}

This study was funded by the European Regional Development Fund Project "Development of Decision Support Tool for Prognosis of Storm Damages in Forest Stands on Peat Soils" (No. 1.1.1.1/16/A/260).

\section{REFERENCES CITED}

Ancelin, P., Courbaud, B., and Fourcaud, T. (2004). "Development of an individual treebased mechanical model to predict wind damage within forest stands," Forest Ecology and Management 203(1-3), 101-121. DOI: 10.1016/j.foreco.2004.07.067

Bušs, K. (1976). Basis of Forest Classification in SSR of Latvia, LRZTIPI Riga, Riga, Latvia. (In Latvian)

Caudullo, G., Tinner, W., and De Rigo, D. (2016). "Picea abies in Europe: Distribution, habitat, usage and threats," in: European Atlas of Forest Tree Species, J. San-MiguelAyanz, D. De Rigo, G. Caudullo, T. Houston Durrant, and A. Mauri (eds.), Publication Office of the European Union, Luxembourg, Luxembourg, pp. 114-116.

Classon, S., Sahlen, K., and Lundmark, T. (2001). "Functions for biomass estimation of young Pinus sylvestris, Picea abies and Betula spp. from stands in Northern Sweden with high stand densities," Scandinavian Journal of Forest Research 16(2), 138-146. DOI: $10.1080 / 028275801300088206$

Cucchi, V., Meredieu, C., Stokes, A., De Coligny, F., Suarez, J., and Gardiner, B. A. (2005). "Modelling the windthrow risk for simulated forest stands of Maritime pine (Pinus pinaster Ait.)," Forest Ecology and Management 213(1-3), 184-196. DOI: 10.1016/j.foreco.2005.03.019

Gardiner, B. A., Byrne, K., Hale, S. E., Kamimura, K., Mitchell, S. J., Peltola, H., and Ruel, J. C. (2008). "A review of mechanistic modelling of wind damage risk to forests," Forestry 81, 447-463.

Krišāns et al. (2020). "Spruce above-ground biomass," BioResources 15(2), 4314-4322. 4319 
Gardiner, B., Peltola, H., and Kellomäki, S. (2000). "Comparison of two models for predicting the critical wind speeds required to damage coniferous trees," Ecological Modelling 129(1), 1-23. DOI: 10.1016/S0304-3800(00)00220-9

Greiss, V. C., Acevedo, R., Härtl, F., Staupendahl, K., and Knoke, T. (2012). 'Does mixing tree species enhance stand resistance against natural hazards? A case study for spruce," Forest Ecology and Management 276, 284-296. DOI: 10.1016/j.foreco.2011.11.035

IPCC (2019). "Summary for policymakers," in: Climate Change and Land: An IPCC Special Report on Climate Change, Desertification, Land Degradation, Sustainable Land Management, Food Security, and Greenhouse Gas Fluxes in Terrestrial Ecosystems [P.R. Shukla, J. Skea, E. Calvo Buendia, V. Masson-Delmotte, H.-O. Pörtner, D. C. Roberts, P. Zhai, R. Slade, S. Connors, R. van Diemen, M. Ferrat, E. Haughey, S. Luz, S. Neogi, M. Pathak, J. Petzold, J. Portugal Pereira, P. Vyas, E. Huntley, K. Kissick, M. Belkacemi, J. Malley, (eds.)]. In press

Jansons, A., Matisons, R., Krišāns, O., Puriņa, L., Džeriņa, B., and Nemiane, U. (2014). "Height of the mass point and some properties of crown of 26 year old scots pine and Lodgepole pine as potential parameters for wind damage in Zvirgzde, Latvia," Baltic Forestry 20(1), 48-57.

Kenina, L., Bardulis, A., Matisons, R., Kapostins, R., and Jansons, A. (2018).

"Belowground biomass models for young oligotrophic Scots pine stands in Latvia," iForest - Biogeosciences and Forestry 11(2), 206-211. DOI: 10.3832/ifor2553-010

Kennedy, F. (2002). The Identification of Soils for Forest Management, Forestry Commission, Edinburgh, Scotland.

Lehtonen, A., Makipaa, R., Heikkinen, J., Sievanen, R., and Liski, J. (2004). "Biomass expansion factors (BEFs) for Scots pine, Norway spruce and birch according to stand age for boreal forests," Forest Ecology and Management 188(1-3), 211-224. DOI: 10.1016/j.foreco.2003.07.008

Lībiete, Z., Matisons, R., Rieksts-Riekstiņš, J., Priedītis, A., Jansons, J., Smilga, J., Done, G., and Jansons, A. (2017). "Above-ground biomass models of 40-year-old Norway spruce in Latvia," Baltic Forestry 23(2):515-521

Marklund, L. G. (1988). Biomass Functions for Pine, Spruce and Birch in Sweden (Report 45), Institutionen för Skogstaxering [Department of Forest Survey], Umeja, Sweden.

Mickovski, S. B., Stokes, A., and Van Beek, L. P. H. (2005). "A decision support tool for windthrow hazard assessment and prevention," Forest Ecology and Management 216(1-3), 64-76. DOI: 10.1016/j.foreco.2005.05.043

Mikšys, V., Varnagiryte-Kabasinskiene, I., Stupak, I., Armolaitis, K., Kukkola, M., and Wojcik, J. (2007). "Above-ground biomass functions for Scots pine in Lithuania," Biomass and Bioenergy 31(10), 685-692. DOI: 10.1016/j.biombioe.2007.06.013

Moore, J. R., and Maguire, D. A. (2007). "Simulating the dynamic behaviour of Douglasfir trees under applied load by the finite element method," Tree Physiology 28(1), 7583. DOI: $10.1093 /$ treephys/28.1.75

Nicoll, B. C., Gardiner, B. A., Rayner, B., and Pearce, A. J. (2006). "Anchorage of coniferous trees in relation to species, soil type, and rooting depth," Canadian Journal of Forest Research 36(7), 1871-1883. DOI: 10.1139/x06-072 
Pajtik, J., Konopka, B., and Lukac, M. (2008). "Biomass functions and expansion factors in young Norway spruce (Picea abies [L.] Karst) trees," Forest Ecology and Management 256(5), 1096-1103. DOI: 10.1016/j.foreco.2008.06.013

Peltola, H., Ikonen, V. P., Gregow, H., Strandman, H., Kilpeläinen, A., Venäläinen, A., and Kellomäki, S. (2010). "Impacts of climate change on timber production and regional risks of win-induced damage to forests in Finland," Forest Ecology and Management 260(5), 833-845. DOI: 10.1016/j.foreco.2010.06.001

Peltola, H., Kellomäki, S., Väisänen, H., and Ikonen, V. P. (1999). “A mechanistic model for assessing the risk of wind and snow damage to single trees and stands of Scots pine, Norway spruce, and birch," Canadian Journal of Forest Research 29(6), 647661. DOI: 10.1139/x99-029

Pivato, D., Dupont, S., and Brunet, Y. (2014). "A simple tree swaying model for forest motion in windstorm conditions," Trees 28, 281-293. DOI: 10.1007/s00468-0130948- z

Pyatt, D. G. (1982). Soil classification. Forestry Commission, Wrecclesham, England.

Pyatt, G., Ray, D., and Fletcher, J. (2001). An Ecological Site Classification for Forestry in Great Britain, Forestry Commission, Edinburgh, Scotland.

R Core Team (2019). "R: A language and environment for statistical computing," Rproject, (http://www.R-project.org/), Accessed 4 Feb 2020.

Repola, J. (2009). "Biomass equations for Scots pine and Norway spruce in Finland," Silva Fennica 43(4), 625-647. DOI: 10.14214/sf.184

Rudnicki, M., Mitchell, S. J., and Novak, M. D. (2004). "Wind tunnel measurements of crown streamlining and drag relationships for three conifer species," Canadian Journal of Forest Research 34(3), 666-676. DOI: 10.1139/x03-233

Schindler, D., Bauhus, J., and Mayer, H. (2012). "Wind effects on trees," European Journal of Forest Research 131, 159-163.

Scott, R. E., and Mitchell, J. S. (2005). "Empirical modelling of windthrow risk in partially harvested stands using tree, neighbourhood, and stand attributes," Forest Ecology and Management 218(1-3), 193-209. DOI: 10.1016/j.foreco.2005.07.012

Sellier, D., Brunet, Y., and Fourcaud, T. (2008). "A numerical model of tree aerodynamic response to a turbulent airflow," An International Journal of Forest Research 81(3), 279-297. DOI: 10.1093/forestry/cpn024

Socha, J. (2012). "Long-term effect of wetland drainage on the productivity of Scots pine stands in Poland," Forest Ecology and Management 274, 172-180. DOI: 10.1016/j.foreco.2012.02.032

Spalvins, A., Slangens, J., Lace, I., Aleksans, O., and Krauklis, K. (2012). "Regional hydrogeological model of Latvia for management of its groundwater resources," in: Proceedings of the International Conference on Applied Information and Communication Technologies (AICT2012), Riga Technical University, Rīga, Latvia, pp. 135-144.

Von Gadow, K., and Hui, G. (2001). Modelling Forest Development, Kluwer Academic Publishers, Dordrecht, Netherlands.

Wirth, C., Schumacher, J., and Schulze, E. D. (2004). "Generic biomass functions for Norway spruce in Central Europe - A meta-analysis approach toward prediction and uncertainty estimation," Tree Physiology 24(2), 121-139. DOI:

10.1093/treephys/24.2.121 
Zianis, D., Muukkonen, P., Makipaa, R., and Mencuccini, M. (2005). "Biomass and stem volume equations for tree species in Europe," Silva Fennica Monographs 4, 41-63.

Article submitted: February 4, 2020; Peer review completed: April 11, 2020; Revised version received and accepted: April 16, 2020; Published: April 20, 2020.

DOI: $10.15376 /$ biores.15.2.4314-4322 